\title{
PELATIHAN DAN BIMBINGAN MASYARAKAT MELAUI PERENCANAAN JARINGAN KERJA UNTUK MEMPERCEPAT PEKERJAAN PROYEK PADA KELOMPOK MANDOR DAN TUKANG BANGUNAN, DI KELURAHAN CEMOROKANDANG, KOTA MALANG
}

\author{
R. Sugeng Basuki, Dandung Novianto, Joko Samboro, M. Maskan, Tatiana Kristianingsih \\ Nilawati Fiernaningsih5 \\ (nilafh@yahoo.co.id)
}

\begin{abstract}
Abstrak - Tujuan Pengabdian Kepada Masyarakat ini, untuk: Meningkatkan pengetahuan (knowledge) kelompok sasaran dalam bidang manajemanen proyek, Menumbuh kembangkan sikap dan perilaku mental (mental attiude dan behaviour) ke arah kerja yang jujur dan efektif, Agar kelompok sasaran memiliki keterampilan dalam dalam melaksanakan manajemen proyek. Metode yang di gunakan adalah: 1.Metode curah pendapat, yaitu untuk menghimpun kebutuhan belajar sumber-sumber dan hambatan terkait dengan pendidikan dan pelatihan, 2.Metode penyusunan pecahan bujur sangkar (broken quare), yaitu untuk menumbuhkan kerjasama antara sesame rekan kerja, 3.Metode ceramah bervariasi, yaitu untuk memberikan informasi tentang manajeman proyek dan organisasi. 4. Metode kerja kelompok, yaitu memberikan kesempatan kepada kelompok sasaran untuk melakukan praktek dalam melakukan manajemen proyek dan organisasi, Pembahasan Masalah Kasus: Metode ini digunakan untuk memecahkan masalah/kasus yang mungkin timbul saat mengerjakan proyek-2 yang berbeda dengan proyek yang bisanya dikerjakan. Hasil Pengabdian Kepada Masyarakat ini Pengabdian ini diikuti dengan praktek yang mempunyai tujuan membekali ketrampilan penerapan penerapan setiap kegiatan, meskipun dengan suasana nonformal tapi sangat relevan bagi peserta dalam rangka meningkatkan ketrampilan teknisnya. Agar pengetahuan dan ketrampilan dan aplikasi yang telah diberikan tidak hilang, maka perlu kiranya bagi Pimpinan untuk memotivasi anggotanya agar dapat berlatih dan dapat lebih meningkatkan lagi. Untuk lebih banyak memperdalam dan memperoleh ketrampilan yang lain maka perlu kiranya ditingkatkan kerja sama dengan lembaga perguruan tinggi khususnya sehubungan dengan kegiatan pengabdian pada masyarakat.
\end{abstract}

Kata kunci: proyek, bangunan, ketrampilan.

\section{PENDAHULUAN}

\subsection{Latar Belakang}

Kondisi Sosial, Ekonomi Penduduk, Kelurahan Cemorokandang, Kecamatan Kedungkandang mayoritas memiliki tingkat usia produktif, yaitu usia antara 21-49 tahun, ini berarti merupakan sumber tenaga kerja. Dengan kondisi penduduk seperti ini maka dibutuhkan lapangan pekerjaan yang memadai yang dapat menampung mereka agar bisa bekerja. Di Kelurahan Cemorokandang tidak ada pabrik atau perusahaan yang dapat menampung. Ini dikarenakan selain mayoritas penduduk sebagai petani dengan hanya mengandalkan tanh gersang selain itu mereka mengembangkan usaha lain sebagai pedagang, PNS, juga industri rumah tangga lainnya, selain itu juga ada yang bekerja pada perusahaan atau pabrik yang ada di wilayah Kodya Malang. Namun demikian masyarakat di Kelurahan Cemorokandang masih banyak yang hidup pada kondisi pra sejahtera karena tingkat pendidikan nya yang relative masih rendah.

Berdasarkan data penduduk menurut mata pencaharian ada $1.360(8,45 \%)$ penduduk Kelurahan Cemorokandang bermata pencaharian sebagai buruh bangunan/tukang, dan mereka hidup pada kondisi pra sejahtera/kondisi miskin. Miskin yang dimaksudkan di sini adalah miskin dalam bidang ekonomi dan pengetahuan.

Kondisi ini makin diperparah dengan tingkat pendidikan masyarakatnya yang pada umumnya masih rendah.

Dalam upaya mengatasi permasalahan yang dihadapi oleh para buruh bangunan/tukang telah dilakukan upaya membentuk kelompok dengan nama "Cak Mad Sejahtera". Kelompok tukang bangunan Cat Mat Sejahtera telah melakukan kegiatan rutin, yaitu pertemuan setiap bulan dan mengadakan kegiatan arisan dan simpan pinjam. Kegiatan kelompok memang sudah berjalan dan memberikan manfaat bagi para anggotanya, namun belum berjalan efektif.

Dalam usaha peningkatan pengetahuan maka mereka perlu diberikan pelatihan dan bimbingan untuk mengefisiensikan pekerjaan mereka sebagai mandor, tukang maupun kuli bangunan.

Hal ini perlu dilakukan agar kinerja mereka dalam menyelesaikan pekerjaan nya diproyek dapat selesai tepat waktu dan dapat menghemat biaya yang dikeluarkan. Dengan demikian mereka dapat mengerjakan proyek-proyek lain yang menunggunya. Ketidak efektifan mereka dalam bekerja pada dasarnya kurangnya pengetahuan mereka dalam mengerjakan suatu proyek.

Dengan demikian dapat disimulkan semakin cept mereka mengerjakan proyek maka semakin banyak pekerjaan proyek yang dapat diselesaikan maka akan meningkatkan penghasilan mereka.

Bertitik tolak pada kenyataan tersebut, perlu kiranya dilakukan suatu usaha untuk memperdayakan kelompok tukang bangunan tersebut melalui pelatihan dan bimbingan mengenai peningkatan kemampuan mereka dalam bidang penyelesaian suatu proyek. Proyek yang dimaksud disini adalah penyelesaian setiap borongan banunan atau pembangunan rumah yang umumnya mereka kerjakan. 


\section{TINJAUAN PUSTAKA}

\subsection{Makna percepatan proyek/pekerjaan (Network Planning//NWP)}

Pada dasarnya percepatan proyek/pekerjaan dalam bidang apapun dapat dilakukan dalam arti bahwa semua kegiatan yang berupa proyek dalam dipercepat waktunya. Percepatan proyek ini dapat dilakukan dengan menerapkan apa yang disebut Network Planning.

Menurut Kajatno (2010: 70) Network Planning merupakan sebuah alat manajemen yang memungkinkan dapat lebih luas dan lengkapnya perencanaan dan pengawasan suatu proyek.

Cara ini penting sekali bergerak dalam bidang pembangunan gedung, jembatan maupun rumah dan lain-2 nya.

Pada dasarnya suatu proyekm itu dapat merupakan salah satu atau kumpulan dari proyek-proyek yang dapat dikategorikan seperti dibawah ini:

1. Proyek-proyek yang kompleks dengan banyak aktifitas-aktifitas yang saling bergantungan.

2. Proyek-proyek besar/kecil yang banyak menggunakan pekerja/personalia.

3. Proyek-proyek yang mengginakan koordinasi antara bagian/departemen satu dengan lainnya.

4. Proyek-proyek yang harus diselesaikan dengan waktu yang tepat dan dengan biaya yang terbatas.

Dalam penyusunan suatu proyek pertamatama kita menginventarisasi kegiatan-2 serta logika ketergantungannya satu sama lain. Dengan mengetahui kedua hal tersebut dan dengan menggunakan symbolsimbol dari kegiatan atau peristiwa maka rencana mendetail yang merupakan sebuah Nertwork sudah dapat digambarkan.

Bentuk logika dari ketergantungan dari kegiatan tadi merupakan dasar dari penyusunan Network Planning selanjutnya.

Sesudah semua itu dibuat langkag selanjutnya adalah peninjauan unsure waktu. Hal ini dapat dilihat dari perkiraan berdasarkan pengalaman. Teori dan perhitungan mengenai jangka waktu, waktu penyelesaian tiap-tiap kegiatan kemudian dihitung kapan waktu terjadinya tiap-tiap kegiatan dari permulaan sampai berakhirnya proyek tersebut, sesuai dengan network yang telah digambarkan diatas.

Dalam peninjauan dan analisis mengenai unsure waktu ini dapat dilihat bahwa terdapat sebuah atau lebih lintasan tertentu dari kegiatan network tadi yang menentukan jangka waktu penyelesaian seluruh proyek. Lintasan ini disebut lintasan kritis. Disampin Lintasan kritis terdapat lintasan-lintasan lain. Dari batasan lintasan yang bukan Lintasan kritis ini mempunyai jangka waktu yang lebih pendek disbanding dengan Lintasan kirtis sehingga lintasan yang tidak kiritis ini mempunyai waktu untuk terlambat. Waktu untuk bisa terlambat ini disebut Float.

Float memberikan sejumlah kelonggaran waktu dan elastisitas pada sebuah network dan ini dipakai pada waktu penggunaan network dalam praktek atau digunakan pada waktu mengerjakan penetapan penentuan jumlah material, equipment dan tenaga kerja.

Dengan demikian penggunaan tenaga kerja dapat dilakukan seefisien dan seefektif mungkin.

Pemberdayaan (empowerment) diartikan memberikan kewenangan, mengalihkan kekuatan, atau mendelegasikan otoritas ke tenaga kerja lain. Pemberdayaan juga diartikan sebagai upaya untuk memberi kemampuan atau keberdayaan (Zaenuddin Arief:2002: 27). Dengan demikian pemberdayaan dapat juga dipahami sebagai upaya memampukan individu atau kelompok yang kurang berfungsi agar meningkat dan mempunyai kemampuan yang lebih baik berkaitan dengan peran mereka dalam pekerjaannya. Individu atau kelompok diharapkan memiliki posisi yang meningkat dalam proyek yang sedang dikerjakan

Di samping itu agar mereka dapat mempunyai akses serta memiliki peluang untuk memperoleh sumber-sumber daya, daya tawar kolektif yang tinggi, kemampuan untuk memiliki berbagai pilihan, disiplin, dan memiliki perspektif yang kreatif.

Upaya untuk memperdayakan masyarakat kelompok tukang bangunan dilakukan dengan memberikan wewenang kepada mereka untuk mengambil bagian dalam pengambilan keputusan.

Pendidikan luar sekolah mempunyai peranan dalam mewujudkan masyarakat yang tidak berdaya menjadi berdaya melalui penyelenggaraan program pelatihan dan bimbingan. Upaya pemberdayaan masyarakat melalui program pelatihan dan bimbingasn dapat dilakukan melalui modul unutk memudahkan dicapai apabila dilaksanakan berdasarkan pada kebutuhan nyata masyarakat, berorientasi pada peningkatan mutu kerja dan penghidupan baik dalam aspek ekonomi, sosial, budaaya.

\subsection{Pendidikan dan Pelatihan}

a.Pengertian Pendidikan dan Pelatihan

Menurut UU RI No. 20 Tahun 2003 tentang SikDikNas, Pendidikan adalah usaha sadar dan terencana untuk mewujudkan suasana belajar dan proses pembelajaran agar peserta didik secara aktif mengembangkan potensi 11 dirinya untuk memiliki kekuatan spiritual keagamaan, pengendalian diri, kepribadian, kecerdasan, akhlak mulia serta keterampilan yang diperlukan dirinya, masyarakat, bangsa dan negara

b.Tujuan Pendidikan dan Pelatihan

Menurut Slamet Saksono (1988:79), bahwa tujuan pendidikan dan pelatihan yang diselenggarakan oleh suaatu organisasi atau perusahaan

baik swastaa atau pemerintah adalah:

1. Meningkatkan pengetahuan (knowledge), kemampuan(ability), dan keterampilan (skills) pegawai dalam menjalankan tugas masingmasing. 
2. Menanamkan pengetahuan yang sama mengenai suatu tugas dalam kaitannya dengan yang lain untuk mewujudkan tujuan organisasi perusahaan.

3. Mengusahakan kemampuan dan keterampilan yang sesuai dengan situasi dan kondisi teknologi yang terjadi berhasilnya pembangunan.

4. Menumbuhkan minat dan perhatian pegawai terhadap bidang tugas masing-masing.

5. Memupuk keberanian berfikir kreatif dan berpartisipasi dalam diskusi.

6. Memupuk hubungan kerjasama antar pegawai secara efisien.

7. Menanamkan jiwa kesatuan

8. Mengubah sikap dan tingkah laku mental (mental attiude dan behaviour) pegawai ke arah kerja yang jujur dan efektif.

9. Mengurangi tingkat labour turnover.

10. Mengembangkan karier pegawai.

11. Menumbuhkan rasa turut memiliki dan taanggung jawab pegawai.

12. Mengurangi frekuensi pengawasan.

Berdasarkan uraian tersebut bahwa tujuan pendidikan dan pelatihan adalah untuk meningkatkan pengetahuan (knowledge),kemampuan (ability),keterampilan (skills), memupuk keberanian berfikir kreatif dan berpartisipasi dalam diskusi, memupuk hubungan kerjasama, menanamkan jiwa kesatuan serta mengubah sikap dan tingkah laku mental (mental attiudedan behaviour) ke arah kerja yang jujur dan efektif.

\subsection{Tahap-tahap Pendidikan dan Pelatihan}

Menurut Barnardin dan Rusell dalam Sulistiyani (2003:178) menyatakan bahwa program pelatihan mempunyai tiga tahap aktivitas yang mencakup antara lain:

1) Penilaian kebutuhan pelatihan, yang tujuannya adalah mengumpulkan informasi untuk menentukan dibutuhkan atau tidaknya program pelatihan.

2) Pengembangan program pelatihan (development), bertujuan untuk merancang lingkungan pelatihan dan metode-metode pelatihan yang dibutuhkan guna mencapai tujuan pelatihan.

3) Evaluasi program pelatihan (evaluation),mempunyai tujuan untuk menguji dan menilai apakah program-program pelatihan yang telah dijalani, secara efektif mampu mencapai tujuan yang telah ditetapkan.

Sedangkan menurut Siagan (2003:185-186) bahwa ada langkah-langkah atau tahap-tahap yang perlu ditempuh dalam pelatihan.

Langkah-angkah tersebut adalah:

1) Penentuan Kebutuhan

Analisis kebutuhan itu harus mampu mendiagnosa paling sedikit dua hal, yaitu masalah- masalah yang dihadapi sekarang dan berbagai tantangan baru yang diperkirakan akan timbul di masa depan

2) Penentuan Sasaran

Sasaran yang ingin dicapai itu dapat bersifat teknikal akan tetapi dapat pula menyangkut keperilakuan. Atau mungkin juga kedua-duanya.

Berbagai sasaran harus dinyatakan sejelas dan sekongkret mungkin, baik bagi para pelatih maupun para peserta.

3) Penetapan Isi Program

Sifat suatu program pelatihan ditentukan paling sedikit oleh dua faktor, yaitu hasil analisis penentuan kebutuhan dan sasaran yang hendak dicapai.

4) Identifikasi Prinsip-prinsip Belajar

Prinsip belajar yang layak dipertimbangkan untuk diterapkan berkisar pada lima hal, yaitu partisipasi, repetisi, relevansi, pengalihan dan umpan balik.

5) Pelaksanaan Program

Penyelenggaraan program pelatihan sangat situasional sifatnya. Artinya, dengan penekanan pada perhitungan kepentingan organisasi dan kebutuhan para peserta, penerapan prinsip-prinsip belajar tercermin pada penggunaan teknik-teknik tertentu dalam proses belajar mengajar.

6) Penilaian Pelaksanaan Program

Pelaksanaan program pelatihan dapat dikatakan berhasil apabila dalam diri para peserta pelatihan tersebut terjadi suatu prosestransformasi. Proses transformasi dapat dikatakan baik apabila terjadi dua hal, yaitu peningkatan kemampuan dalam melaksanakan tugas dan perubahan sikap perilaku yang tercermin dalam sikap, disiplin dan etos kerja.

\section{METODE PELAKSANAAN}

\subsection{Khalayak Sasaran}

Sasaran kegiatan ini adalah anggota dan pengurus kelompok tukang bangunan di Jln. Sampurna, Kelurahan Cemorokandang , Kecamatan Kedungkandang, Malang yang mana sekitar 75 \$ penduduknya memiliki pekerjaan dibidang bangunan dan berpendidikan SD, SMP, dan SMA.

\subsection{Metode PPM}

Rencana aksi Pengabdian Pada Masyarakat oleh tim dari Jurusan Administrasi Niaga di Kelurahan Cemorokandang ini diselenggarakan selama 3 (tiga) bulan dan dilanjutkan dengan model pendampingan selama 3 bulan (sampai 1 September 2018 dalam pertemuan kelompok tukang bangunan sua minggu sekali. Kegiatan ini melibatkan pengurus dan anggota kelompok tukang bangunan yang masih baru maupun yang sduah lama keanggotaannya di kelompok ini. Kegiatan pemberdayaan kelompok tukang bangunan yang meliputi kegiatan akademik dan praktek profesional ini dilakukan dengan menggunakan variasi metode pembelajaran agar pemahaman setiap anggota kelompok tukang bangunan ini semakin tertanam dan mempribadi dalam setiap tugasnya melakukan pelayanan terhadap masyarakat. 
Sebagaimana diuraikan sebelumnya bahwa proses pembelajaran dilaksanakan dengan berbagai variasi dalam mencapai target, tujuan dan kemanfaatan kegiatan adalah :

1. Metode curah pendapat, yaitu untuk menghimpun kebutuhan belajar sumber-sumber dan hambatan terkait dengan pendidikan dan pelatihan.

2. Metode penyusunan pecahan bujur sangkar (broken quare), yaitu untuk menumbuhkan kerjasama antara sesame rekan kerja.

3. Metode ceramah bervariasi, yaitu untuk memberikan informasi tentang manajeman proyek dan organisasi.

4. Metode kerja kelompok, yaitu memberikan kesempatan kepada kelompok sasaran untuk melakukan praktek dalam melakukan manajemen proyek dan organisasi.

5. Pembahasan Masalah Kasus.

Metode ini digunakan untuk memecahkan masalah/kasus yang mungkin timbul saat mengerjakan proyek-2 yang berbeda dengan proyek yang bisanya dikerjakan.

\subsection{Rancangan Evaluasi Pelaksanaan}

Kegiatan pendidikan pelatihan dikatakan berhasil apabila dalam pelatihan terjadi proses transformasi pengetahuan. Proses transformasi dapat dikatakan baik apabila terjadi dua hal, yaitu peningkatan kemampuan dalam melaksanakan tugas dan perubahan sikap perilaku yang tercermin dalam sikap, disiplin dan etos kerja dalam kelompok.

Jadi setelah materi alih proses pengetahuan disiapkan, diberikan pertanyaan kepada calon peserta. Kemudian langsung di evaluasi baik mengenai metode maupun materi yang akan disampaikan pada saat alih pengetahuan yang sesungguhnya. Tujuannya agar saat pelaksanaan semua materi dapat dicerna dengan mudah oleh peserta.

Evaluasi proses juga diterapkan oleh Tim PPM terutama pada saat pola pendampingan dalam beberapa kali pertemuan kelompok tukang khususnya pada saat melakukan praktek manajemen proyek. Evaluasi pada tahap ini meliputi tahap-tahap sebagai berikut:

- Evaluasi terhadap hambatan-hambatan yang dihadapi baik dalam penyampaian materi maupun hal-hal yang bersifat tehnis.

- Evaluasi kelayakan ,ateri yang diberikan.

- Evaluasi daya penerimaan/penyerapan materi yang disampaikan.

\subsection{Tolak Ukur Keberhasilan}

Untuk menilai keberhasilan metode maupun materi yang disampaikan dilaksanakan dengan cara membuat daftar pertanyaan yang nantinya diajukan pada peserta lain. Evaluasi terhadap kemampuan peserta.

Dari hasil transfer pengetahuan dan dialog dengan peserta di lapangan, maka peserta dibagi menjadi 3 peringkat sebagai berikut:

- Peingkat I : peserta dianggap mempunyai kemampuan lebih

- Peingkat II : peserta dianggap mempunyai kemampuan rata-rata
- $\quad$ Peingkat III : peserta dianggap mempunyai kemampuan kurang.

\subsection{Evaluasi akhir kegiatan PKM}

Dari hasil keseluruhan pelaksanaan bimbingan pelatihan PKM ini, akan dinilai factor-faktor penghambat dan pendorong yang didapatkan dalam pelaksanaan kegiatan.

Untuk menilai factor-faktor penghambat dan pendorong dilakukan dengan cara mengumpulkan data-data yang diperoleh pada waktu proses bimbingan dari tahap awal sampai tahap akhir pelaksanaan bimbingan ini.

Data tersebut dianalisis utnuk mengetahui factor-faktor penghambat dan pendorong keberhasilan bimbingan tentang penerapan network planning ini.

\section{PEMBAHASAN}

\subsection{Pelaksanaan Kegiatan}

Untuk mengevaluasi tentang seberapa jauh keberhasilan dari Pengabdian ini terlebih dahulu dibuat tentang :

1. Tujuan yang akan dicapai

2. Sasarannya

3. Manfaat yang akan diperoleh

\subsection{Tujuan yang akan dicapai}

Tujuan dari Pengabdian Masyarakat ini adalah untuk menemukan alternatif pembinaan yang tepat guna melalui

a. Meningkatkan pengetahuan dan kemampuan Industri Kecil di bidang pengelolaan organisasi

b. Meningkatkan aplikasi hasil penyuluhan dan pelatihan ini dalam rangka pengembangan Iptek

c. Menciptakan peluang kesempatan kerja dalam kegiatan ekonomi masyarakat dalam bentuk peningkatan pendapatan

d. Menjalin hubungan yang lebih erat antara Politeknik Unibraw dengan Industri Kecil khususnya tukang bangunan desa Cemorokandang.

Setelah mengadakan pengabdian kepada masyarakat, maka dalam melihat keberhasilannya harus dilihat dari hasil kegiatan tersebut. Saat ini memang harus diakui hasilnya belum nampak, tetapi berdasarkan hasil pengamatan selama ini tanda-tanda kearah itu dapat dikatakan mereka pada umumnya telah bisa menghitung keuntungan yang layak.

Dengan adanya tingkat pendidikan yang berbedabeda, maka dalam menyerap materi yang diajarkan hasilnya masih dapat dikatakan belum terserap secara merata. Namun demikian secara umum dapat dikatakan secara keseluruhan materi yang diberikan dapat dimengerti oleh mereka.

Pada umumnya peserta pengabdian masyarakat masyarakat kecil yang mempunyai keinginan cukup besar untuk menambah pengetahuannya. Justru disinilah letak keberhasilan Pengabdian ini.

\subsection{Sasaran}


Sasaran yang dapat dicapai pada kelompok atau individu, diharapkan nantinya dapat dijadikan bekal dalam rencana untuk memperoleh tambahan pendapatan atas usahanya.

\subsection{Pembahasan}

Dengan pengabdian ini diharapkan pengusaha kecil mampu membuat sistem Manajemen dan Pengelolaan Organisasi untuk:

- Efisiensi kerja .

- Mengurangi biaya tenaga kerja.

- Peningkatan sumber pendapatan utama pengusaha.

- Kwalitas kerja dapat dipertahankan atau ditingkatkan.

- Daya guna/manfaat hasil kerja akan lebih tinggi.

- Diharapkan mampu menekan dampak negatif dari pengangguran.

- Menciptakan kesempatan kerja yang lebih luas.

Keberhasilan pengabdian pada masyarakat ini belum dapat dilihat secara langsung, hal ini akan terjadi jika nantinya telah benar=benar diterapkan oleh manddor tukang tersebut. Namun jika dilihat dari hasil yang dicapai maka manfaatnya adalah dengan bertambahnya pengetahuan dan wawasan yaitu dengan telah mendapat pengetahuan ketrampilan tentang pengelolaan manajemen dan organisasi yang benar, sehingga diharapkan dengan adanya tambahan pengetahuan ini dapat membantu mereka dalam mengantisipasi berbagai masalah yang dihadapinya.

Setelah Pelaksanaan Pengabdian pada Masyarakat tentang, dapat dievaluasi sbb :

\section{- Faktor Penghambat}

Pelaksanaan kegiatan pengabdian pada masyarakat ini dirasa tidak ada faktor penghambat yang serius. Barangkali dapat dijelaskan disini, bahwa kondisi peserta berbeda-beda tingkat pendidikannya, hal ini tidak menyebabkan daya serap materi kurang bisa lancar. Dan ditambah dengan kesabaran dan ketelatenan instruktur, kondisi diatas malah semakin mengasyikkan.

\section{- Faktor Pendorong.}

- Dengan terselenggaranya pengabdian pada masyarakat ini dirasakan ada beberapa faktor pendorong yang menjadikan kegiatan ini dapat dilaksanakan dengan lancar, yaitu :

- Minat dan semangat para peserta dalam mengikuti pengabdian sangat besar sekali, sehingga mempermudah dalam proses belajar mengajar dan pemberian motivasi, meskipun dalam kondisi yang sederhana.

- Pimpinan mempunyai tekad besar sehingga dapat mendorong terlaksananya aktivitas pengabdian pada masyarakat ini.

- Para pengajar dan instruktur yang selalu siap pada materi dan alat bantu pengajarannya, hal ini memperlancar dalam pelaksanaan proses pengajarannya.

\section{- Evaluasi}

Setelah selesainya kegiatan pengabdian pada masyarakat maka hasilnya dapat dievaluasi sebagai berikut :

- Relevansi : Pengabdian ini diikuti dengan praktek yang mempunyai tujuan membekali ketrampilan penerapan pengelolaan keuangan, meskipun dengan suasana nonformal sangat relevan bagi peserta dalam rangka meningkatkan kemajuan anggotanya.

- Acceptabilitas : Pengabdian yang diberikan mudah dikuasai oleh peserta, karena materinya bersifat praktis, walaupun pesertanya terdiri dari beberapa tingkat pendidikan, hanya diperlukan ketekunan dan daya kreativitas.

- Efektifitas : untuk kerja individu sangat memungkinkan sekali terutama bagi mereka yang mempunyai daya kreativitas yang tinggi.

- Ketepatan : Ketrampilan yang diberikan sangat tepat sekali, karena mudah dipelajari dan berguna sebagai bekal dihari kelak.

- Kegunaan : Materi ini sangat berguna untuk mengantisipasi di keadaan masa datang, yang berhubungan dengan mengembangkan usaha.

- Pengaruh jangka panjang : akan membawa kemajuan di lingkungannya dalam rangka mensukseskan program pemerintah dan membekali pengetahuan dan ketrampilan.

- Daya ulang dan kreativitas : untuk menerapkan ketrampilan dengan lancar dan baik, harus selalu diadakan latihan yang serius dan kontinyu agar bekal ketrampilan yang telah diberikan tidak hilang.

\subsection{Luaran yang dicapai}

- Para mandor telah mengerti dan memehami arti pentingnya pembuatan suatu perencanaa kerja sebelum mereka mengerjakan suatu proyek.

- Mereka lebih detail dalam menghitung biaya yang harus dikeluarkan untuk menyelesaikan suatu proyek

- Lebih efisien dalam perhitungan biaya dan waktu yang dibutuhkan dalam menyelesaikan proyek,

- Setiap pekerjaan proyek dapat dikerjakan lebih cepat

- Merela lebij mampu mengkoordinir pembantunya/tukang dalam menyelesaikan setiap kegiatan

- Lebih tepat dalam membuat perjanjian dengan pemilik bangunan dalam peneyelesaian waktunya.

\section{SIMPULAN DAN SARAN}

\subsection{Kesimpulan}


Dengan telah selesainya kegiatan pengabdian pada masyarakat ini maka dari hasil mulai dari awal sebelum pelaksanaan hingga sampai dengan evaluasi hasil akhir dari pengabdian pada masyarakat ini, maka dapat diambil beberapa kesimpulan yaitu :

- Pengabdian ini adalah merupakan kegiatan dan pengetahuan serta aplikasi yang sangat penting dalam rangka usaha untuk memperoleh tambahan pengetahuan dan ketrampilan bagi masyarakat di desa Cemorokandang.

- Motivasi peserta sangat tinggi, hal ini terlihat dari antusiasnya peserta mengikuti sampai akhir program.

- Dari hasil pengamatan selama proses kegiatan ini berlangsung maka dapat dilihat bahwa rata-rata penerimaan materi yang disampaikan oleh instruktur cukup baik.

- Untuk lebih meningkatkan ketrampilan yang telah diperoleh maka perlu kiranya para peserta untuk lebih banyak berlatih.

\subsection{Saran-Saran}

- Agar pengetahuan dan ketrampilan dan aplikasi yang telah diberikan tidak hilang, maka perlu kiranya bagi Pimpinan untuk memotivasi anggotanya agar dapat berlatih dan dapat lebih meningkatkan lagi.

- Untuk lebih banyak memperdalam dan memperoleh ketrampilan yang lain maka perlu kiranya ditingkatkan kerja sama dengan lembaga perguruan tinggi khususnya sehubungan dengan kegiatan pengabdian pada masyarakat.

- Dengan selesainya kegiatan pengabdian pada masyarakat ini diharapkan agar lebih mempererat hubungan dan kerja sama antara Pihak Ketua/Mandor Tukang Bangunan dengan Politeknik Negeri Malang.

\section{Daftar Rujukan}

[1]. Hadi Sudjana. (2005). Metode dan Teknik Pembalajaran Partisipatif. Bandung: Falah Production.

[2]. Slamet Saksono. (2006). Adminstrasi Kepegawaian.Yogyakarta: Kanisius.

[3]. Soetomo Kajatno (2008), Network Planning, Badan Penerbit Pekerjaan Umum.

[4]. Sulistiayani, AmbarT. dan Rosidah. (2003). Manajemen Sumber Daya Manusia.Yogyakarta: Graha Ilmu.

[5]. Susilo Martoyo. (2009). Manajemen Sumber Daya Manusia.Yogyakarta: BPFE.

[6]. Undang-Undang Republik Indonesia Nomor 20 Tahun 2003 tentang Sistem Pendidikan Nasional.

[7]. Wursanto. (2004). Manajemen Kepegawaian. Yogyakarta: Kanisius.

[8]. Zaenuddin Arif. (2006). Pengelolaan dan Pemberdayaan PKBM. Makalah: Lokakarya Penyusunan Kurikulum Inti Prodi PLS tanggal 2224 Agustus 2002 di PPS UNY
[9]. 8. Hadi Sudjana. (2008). Metode dan Teknik Pembalajaran Partisipatif. Bandung: Falah Production. 